Vol. 44, N. 4 : pp. 433 - 438, December, 2001

ISSN 1516-8913 Printed in Brazil

\title{
Metabolism and Gaseous Exchanges in Two Coastal Lagoons from Rio de Janeiro with Distinct Limnological Characteristics
}

\author{
Sidinei M. Thomaz ${ }^{1 *}$; Alex Enrich-Prast ${ }^{2}$; José F. Gonçalves Jr. ${ }^{2}$; Anderson M. dos Santos ${ }^{3}$ \\ and Francisco A. Esteves ${ }^{2}$ \\ ${ }^{1}$ Universidade Estadual de Maringá, DBI, Nupelia - Av. Colombo, 5790, Maringá - PR, Brazil; ${ }^{2}$ Universidade Federal do \\ Rio de Janeiro, Dep. Ecologia - Ilha do Fundão, Rio de Janeiro - RJ, Brazil; ${ }^{3}$ Universidade Estadual de Maringá, Curso \\ de Pós graduação em Ecologia de Ambientes Aquáticos Continentais - Av. Colombo, 5790, Maringá - PR, Brazil
}

\begin{abstract}
The global metabolism and exchange of gases with the atmosphere were measured during a diel cycle in two tropical coastal lagoons, using the curves of carbon dioxide and dissolved oxygen. Heterotrophic metabolism (net $\mathrm{CO}_{2}$ production and net $\mathrm{O}_{2}$ consumption) was observed in a black water lagoon (Comprida), and autotrophic metabolism (net $\mathrm{O}_{2}$ production and net $\mathrm{CO}_{2}$ consumption) in a clear water lagoon (Imboassica). These differences were attributed to the limnological characteristics of both ecosystems, especially to dissolved organic carbon and the attenuation coefficient of light, which are much higher in the first environment. During the diel cycle analyzed there was a net release of carbon dioxide into the atmosphere in the first lagoon and a net uptake by the water in the second one. Thus, the importance of coastal lagoons for the global carbon budget deserves further study.
\end{abstract}

Key words: Coastal lagoon, global metabolism, heterotrophic activity, microbial respiration, diel variation

\section{INTRODUCTION}

The coastal lagoons are among the most important aquatic ecosystems in Brazil, being found from the state of Rio Grande do Sul up to the state of Maranhão. These ecosystems are relatively shallow (depth usually less than 5 meters), being exposed to the constant action of winds (Esteves et al., 1988). Nowadays, many lagoons receive special attention because they are being subjected to an intense anthropogenic action which, not unusually, leads to an extensive degree of degradation caused by eutrophication (Knoppers, 1994).

Factors related to their origin (marine or fluviomarine), to the degree of connection with the ocean and to the kind of influx result in a considerable variety of coastal lagoons. In a typology proposed by Esteves et al. (1983), lagoons of brackish and clear waters and of brackish and dark waters as well as lagoons of fresh and clear waters and of fresh and dark waters may be found.

The total metabolism of an ecosystem is equal to the difference between how much is produced and consumed or respired. Environments with a production greater than respiration during 24 hours period may be considered autotrophic, while environments with respiration greater than production during 24 hours period may be considered heterotrophic (Carmouze et. al., 1991). The metabolism of the lagoons may differ due to the influx of organic matter and nutrients, among other

*Author for correspondence 
factors. The analysis of the daily budget of gases such as dissolved oxygen and carbon dioxide may be regarded as an important tool in evaluating the metabolism of these ecosystems, since the dynamics of these gases is directly related to primary production and respiration/decomposition. Therefore, the results of the daily budgets of dissolved oxygen or carbon dioxide point directly to the levels of autotrophy or heterotrophy of the aquatic ecosystems. Among the techniques employed, the evaluation of the daily budget in the body of water as a whole, with samples obtained "in situ", i. e., not incubated, has been used with success (Carmouze et al., 1991; Landim de Souza and Couto, 1997; Paes da Silva and Thomaz, 1997).

In the present study, the metabolism of two coastal lagoons (Imboassica and Comprida) was simultaneously evaluated in a 24 hour cycle. The chosen lagoons differ considerably in their concentrations of dissolved organic carbon, light penetration and primary producers (Tab. 1).

\section{STUDY AREA}

The two lagoons studied are located in the municipalities of Carapebus and Macaé respectively $\left(22^{\circ}\right.$ and $22^{\circ} 30^{\prime} \mathrm{S}$ and $41^{\circ} 30^{\prime}$ and $\left.42^{\circ} \mathrm{W}\right)$, State of Rio de Janeiro (Fig. 1). The Comprida lagoon (area of $0.13 \mathrm{~km}^{2}$ ) has dark waters and a depth of 1.8 meters and the Imboassica lagoon (area of $3.26 \mathrm{~km}^{2}$ ) has clear waters and depth of 1.1 meters. The later lagoon has received an influx of domestic effluents rich in $\mathrm{P}$ and $\mathrm{N}$ which are, however, retained in the littoral region (Lopes-Ferreira, 1995). It had a dense stand of Chara sp. during our samplings.

The region's climate is AW type, according to the Köppen classification, warm and humid, mesothermic, with heat well distributed throughout the year, with a maximum average temperature of $29.9^{\circ} \mathrm{C}$ in February and minimum average of 25.4 ${ }^{\circ} \mathrm{C}$ in July (FIDERJ, 1977). The greatest amount of rainfall occurs in spring and summer, the smallest being detected in the winter months. According to the classification of Kjerfve (1986) the geomorphological type of these lagoons is "choked lagoons" (Branco, 1998).

\section{METHODS}

The light penetration - photosynthetically active radiation - was measured with a Lycor aquatic radiometer. The method used for measuring the metabolism of the lagoons ("free water", according Carmouze, 1994), is based on the daily curves of the concentrations of total inorganic carbon dioxide and of the dissolved oxygen. This method, introduced in the beginning of the 50's (Odum, 1957; Talling, 1957), has as main advantages the non-incubation of samples in flasks and the fact that the result represents the communities as a whole (planktonic and benthic) (Knoppes, 1994). This approach is especially valid in the case of Imboassica lagoon, colonized by Chara sp. The metabolism of the two ecosystems was evaluated with the data obtained in four samplings, realized simultaneously in both lagoons, at 18:00 on 08.19.1997 and at 06:00, 12:00 and 18:00 on 08.20.1997. The simultaneity of the samplings and the proximity of the lagoons, exposed to the same conditions of temperature, wind and solar radiation, favors comparisons between these systems.

For estimating the total metabolism of the two lagoons, samples of water were collected at 3 depths in Comprida lagoon (subsurface, 0.8 and 1.5 meters) and at two depths in Imboassica lagoon (subsurface and 0.8 meters). For each sample, the concentrations of total inorganic carbon were determined, according to the procedure described in Carmouze (1994), and of dissolved oxygen, according to Golterman et al. (1978). These data were transformed to concentration by surface area $\left(\mathrm{m}^{2}\right)$ and applied in the BIOLAT program (Carmouze, 1994). According to this author, the rates of net production or net mineralization registered in a determined period, measured through the method of total metabolism, correspond to the differences between the variations of $\mathrm{CO}_{2}$ or of $\mathrm{O}_{2}$ in the water column and the net flows of exchange of these gases in the water-atmosphere interface. The exchanges between the aqueous medium and the atmosphere were estimated according to the Fick's law and the transfer coefficients by unities of time considered the following relationships. 


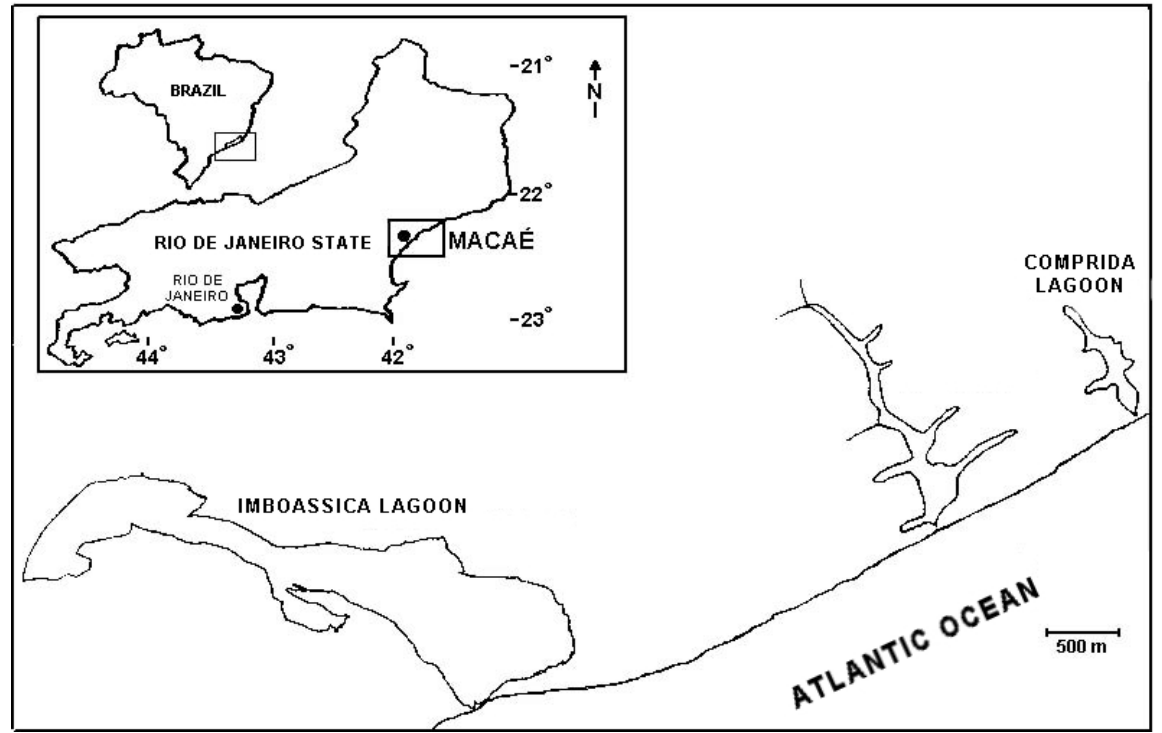

Figure 1 - Location of Imboassica and Comprida lagoons, in the State of Rio de Janeiro.

For carbon dioxide:

$\mathrm{pH}$ between 6 and 9 and wind velocity $(\mathrm{V})<5 \mathrm{~m} / \mathrm{s}: 0.008 \mathrm{~m} / \mathrm{h}$

pH between 6 and 9 and wind velocity $>5 \mathrm{~m} / \mathrm{s}: 9.5 \times 10^{-4} \times \mathrm{V}^{2} \times \mathrm{m} / \mathrm{h}$

$\mathrm{pH}<6$ and wind velocity $<5 \mathrm{~m} / \mathrm{s}: 0.01995 \mathrm{~m} / \mathrm{h}$

$\mathrm{pH}<6$ and wind velocity $>5 \mathrm{~m} / \mathrm{s}: 23.7 \times 10^{-4} \times \mathrm{V}^{2} \times \mathrm{m} / \mathrm{h}$

For dissolved oxygen:

wind velocity $<5 \mathrm{~m} / \mathrm{s}: 0.029 \mathrm{~m} / \mathrm{h}$

wind velocity $>5 \mathrm{~m} / \mathrm{s}: 0.0034 \times \mathrm{V}^{2} \mathrm{x} \mathrm{m} / \mathrm{h}$

The level of autotrophy or heterotrophy of these lagoons was evaluated according to the gas budget through a 24 hour period.

\section{RESULTS AND DISCUSSION}

The annual average concentrations of total-P, Kjeldahl total-N and dissolved organic carbon (DOC) obtained in the two lagoons are shown in Table 1. Imboassica lagoon had higher $\mathrm{pH}$, electrical conductivity and salinity values and lower values of the coefficient of light extinction and of the concentrations of total-P, Kjeldahl total-N and DOC when compared to Comprida lagoon. The higher light penetration (35\% of the surface radiance reach the sediment - Fig. 2) allows for the development of benthic algae (Chara sp.) at Imboassica lagoon. On the other hand, the high concentrations of DOC in Comprida lagoon affect directly the light penetration, causing the high coefficient of light extinction of this lagoon (Tab. 1 and Fig. 2). These differences in the limnological characteristics of these two environments persist throughout the year (Petrucio, 1998).

The sampling period (August) may be considered of low biological activity for this region, due to the lower values of temperature and to the smaller values of solar radiation (Carmouze et al., 1991). Even so, the concentrations of oxygen and carbon dioxide oscillated considerably due to the biological activity through the nictemeral period. At Imboassica lagoon, a build-up in the oxygen levels and a fall in the total carbon dioxide were registered during the light period (Fig. 3). This fact was more prominent in the afternoon period (12:00 to 18:00), when the biological activity resulted in a net production of $107.7 \mathrm{mM} \mathrm{O}_{2} \mathrm{~m}^{2}$ and an uptake of 150 $\mathrm{mM} \mathrm{CO}_{2} \mathrm{~m}^{2}$ (Fig. 3a). On the other hand, Comprida lagoon exhibited a heterotrophic metabolism even in the light period, with a net uptake of $11.3 \mathrm{mM} \mathrm{O}_{2} \mathrm{~m}^{2}$ 
and a production of $52.2 \mathrm{mM} \mathrm{CO}_{2} \mathrm{~m}^{2}$ between 06:00 and 18:00 (Fig. 3b).

Table 1 - Abiotic variables in the studied lagoons.

\begin{tabular}{lll}
\hline Variables & Imboassica & Comprida \\
\hline Temperature $\left({ }^{\circ} \mathrm{C}\right)$ & $23,3^{*}$ & $24,0^{*}$ \\
Coef. of extinction $\left(\mathrm{m}^{-1}\right)$ & $0,697^{*}$ & $4,598^{*}$ \\
$\mathrm{pH}$ & $9,03^{*}$ & $5,12^{*}$ \\
Conductivity $\left(\mathrm{mS} \mathrm{cm}^{-1}\right)$ & $12,2^{*}$ & $4,4^{*}$ \\
Salinity & $10^{*}$ & $3^{*}$ \\
Total-P $(\mu \mathrm{g} / \mathrm{l})$ & $9^{* *}$ & $13^{* *}$ \\
Kjeldahl total-N $(\mu \mathrm{g} / \mathrm{l})$ & $210^{* *}$ & $660^{* *}$ \\
DOC $(\mathrm{mg} / \mathrm{l})$ & $14,3^{* *}$ & $19,1^{* *}$ \\
\hline
\end{tabular}

*daily average of the sampling

**annual average (Farjalla, 1998)

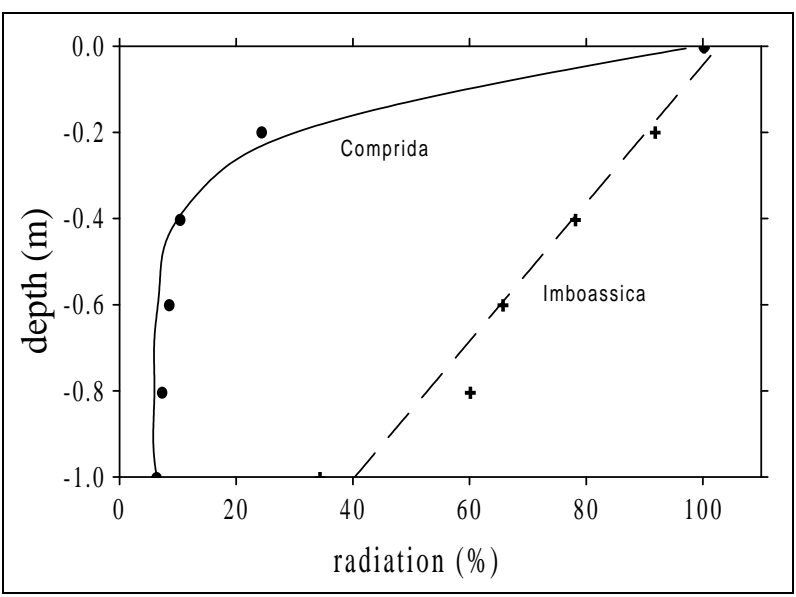

Figure 2 - Profiles of photosynthetically active radiation obtained in the two studied lagoons.

The results of the daily metabolism (biological activity) of the gaseous exchanges between the water column and the atmosphere obtained in the Imboassica and Comprida lagoons are quite different (Tab. 2). Independently of the method used (dissolved oxygen or carbon dioxide), the primary production was greater than the uptake in Imboassica lagoon and the opposite was found in Comprida lagoon. In other words, in the nictemeral cycle studied, the first lagoon had an autotrophic metabolism while the second had a heterotrophic metabolism.

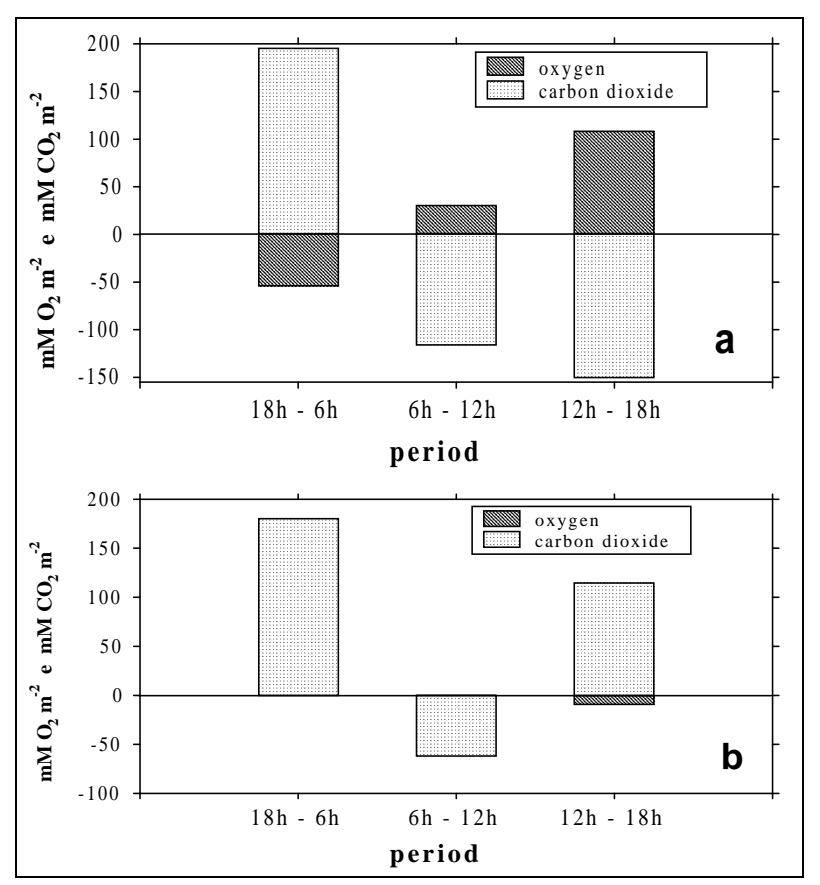

Figure 3 - Total metabolism (biological activity) measured through the nictemeral evolution of the concentrations of dissolved oxygen and carbon dioxide in the water column of the Imboassica (a) and Comprida (b) lagoons. Positive values represent net production and negative, net uptake, in the considered period.

Based on a yearly cycle, the coastal lagoons may present all types of energetic budget, from the autotrophic to an entirely heterotrophic metabolism (Carmouze et al., 1991; Knoppers, 1994). Considering the great inflow of DOC and the reduced light penetration in Comprida lagoon, we may hypothesize that the high degree of heterotrophy found in this study also occurs at other times of the year. The higher penetration of light allied to the colonization by benthic macroalgae in Imboassica lagoon may, on the other hand, propitiate the dominance of an autotrophic metabolism in this lagoon through a seasonal cycle. Nevertheless, we measured only one diel cycle and our results have to be considered with caution. Thus, the carbon budget and the metabolism of both lagoons has still to be addressed considering an entire seasonal cycle.

Heterotrophic metabolism has been measured in other coastal lagoons with dark waters (Landim de Souza and Couto, 1997) and seem to be characteristic of this kind of ecosystem. This behavior may be attributed to the influx of allochthonous DOC, as humic compounds, used by the bacterial community, increasing the rates of secondary production (uptake) related to the primary 
production (Tranvik, 1989). In oligotrophic aquatic ecosystems with dark waters, for instance, the secondary bacterial production may be up to 8 times greater than the primary production (Tranvik, 1989).

Table 2 - Daily budget of the biological activity and of the gaseous exchanges between the water and the atmosphere, measured by the evolution of the concentrations of dissolved oxygen and of total inorganic carbon. Positive values represent an increase and negative values represent a decrease of the gas in the water.

\section{Imboassica Comprida}

$\begin{array}{lll}\text { Primary production: } & & \\ -\mathrm{mM} \mathrm{O}_{2} \mathrm{~m}^{-2} \mathrm{~d}^{-1} & +83,5 & -10,9 \\ -\mathrm{mM} \mathrm{CO}_{2} \mathrm{~m}^{-2} \mathrm{~d}^{-1} & -71,5 & +232,0 \\ \text { Gaseous exchanges: } & & \\ \text { - } \mathrm{mM} \mathrm{CO}_{2} \mathrm{~m}^{-2} \mathrm{~d}^{-1} & +56,7 & -246,0\end{array}$

Another fact worthy of note, resulting from the net heterotrophy of Comprida lagoon, is the considerable diffusion of $\mathrm{CO}_{2}$ into the atmosphere (Tab. 2), which was also shown in other coastal lagoons with dark waters (Landim de Souza and Couto, 1997). Therefore, the importance of these ecosystems for the global budget of carbon dioxide deserves further study.

\section{ACKNOWLEDGEMENTS}

We acknowledge Paulo Roberto Barros Brum and John Stanley for translation into English. S. M. Thomaz belongs to the Research Productivity Program (CNPq).

\section{RESUMO}

O metabolismo global e as trocas gasosas com a atmosfera foram medidos durante um ciclo diurno em duas lagoas costeiras tropicais usando as curvas do dióxido de carbono e do oxigênio dissolvido. Metabolismo heterotrófico (produção líquida de $\mathrm{CO}_{2}$ e consumo líquido de $\mathrm{O}_{2}$ ) foi observado em uma lagoa de águas escuras (Comprida) e metabolismo autotrófico (produção líquida de $\mathrm{O}_{2} \mathrm{e}$ consumo líquido de $\mathrm{CO}_{2}$ ) em uma lagoa de águas claras (Imboassica). Essas diferenças foram atribuídas às características limnológicas de ambos os ecossistemas, especialmente ao carbono orgânico dissolvido e coeficiente de atenuação luminosa, maiores na primeira lagoa. Durante o ciclo diurno analisado, houve liberação líquida de dióxido de carbono para a atmosfera na primeira lagoa e transferência da atmosfera para a água na segunda. Assim, a importância de lagoas costeiras para o balanço global de carbono merece ser investigado com atenção.

\section{REFERENCES}

Branco, C. W. (1998), Composição e aspectos ecológicos das comunidades zooplanctônicas nas lagoas Imboassica, Cabiúnas e Comprida. In - Ecologia das lagoas costeiras do Parque Nacional da Restinga de Jurubatiba e de Macaé (RJ), ed. F. A. Esteves. UFRJ, Rio de Janeiro, pp. 213-235.

Carmouze, J. P. (1994), O metabolismo dos ecossistemas aquáticos. Edgard Blücher/ SBL/FAPESP, São Paulo.

Carmouze, J. P., Knoppers, B. and Vasconcelos, P. (1991), Metabolism of a subtropical Brazilian lagoon. Biogeochemistry, 14, 129-148.

Esteves, F. A.; Barbieri, R.; Ishii, I. H. and Camargo, A. F. M. (1983), Estudos limnológicos em algumas lagoas costeiras do Estado do Rio de Janeiro. An. Sem. Reg. Ecol., 3, 25-38.

Esteves, F. A.; Bozelli, R. L.; Camargo, A. F. M., Roland, F.; Thomaz, S. M. (1988), Variação diária (24 horas) de temperatura, $\mathrm{O}_{2}$ dissolvido, $\mathrm{pH}$ e alcalinidade em duas lagoas costeiras do estado do Rio de Janeiro e suas implicações no metabolismo destes ecossistemas. Acta Limnol. Brasil., 2, 99-127.

Farjalla, V. F. (1998), Nutrientes limitantes ao crescimento do bacterioplâncton nas lagoas Carapebus, Comprida, Cabiúnas e Iodada. In - Ecologia das lagoas costeiras do Parque Nacional da Restinga de Jurubatiba e de Macaé (RJ), ed. F. A. Esteves. UFRJ, Rio de Janeiro, pp. 147-158.

FIDERJ (1977), Estudos para o planejamento ambiental. Fundação Instituto de Desenvolvimento Econômico e Social do Rio de Janeiro, Rio de Janeiro.

Golterman, H. L., Clymo, R. S. and Ohmstad, M. A M. (1978), Methods for physical and chemical analysis of fresh waters. Blackwell Scientific Publication, Oxford.

Knoppers, B. (1994), Aquatic primary production in coastal lagoons. In - Coastal lagoon processes, ed. B. Kjerfve. Elsevier Oceanography Series 60, pp. 243-286.

Kjerfve, B. (1986), Comparative oceanography of coastal lagoons. In -Estuarine variability, ed. D. A. Wolfe. Academic Press, New York, pp. 63-81.

Landim de Souza, M. F. and Couto, E. C. G. (1997), Net phytoplanktonic primary production, respiration and $\mathrm{CO}_{2}$ loss in Gururema lagoon (Northern, Brazil). Arq. Biol. Tecnol., 10, 69-74. 
Lopes-Ferreira, C. M. (1995), O papel de uma região colonizada por macrófitas aquáticas na depuração de efluentes domésticos na Lagoa Imboassica (Macaé, RJ). MSc Thesis, PPGE-UFRJ, Rio de Janeiro.

Mackereth, F. Y. H., Heron, J. G. and Talling, J. J. (1978), Water analysis: some revised methods for limnologists. Freshwater Association, 36.

Odum, H. T. (1956), Primary production in flowing waters. Limnol. Oceanog. 1, 102-117.

Paes da Silva, L. and Thomaz, S. M. (1997), Diel variation of some limnological parameters and metabolism of a lagoon of the high Paraná river floodplain, MS. An. Sem. Reg. Ecol., 7, 169-189.
Petrucio, M. M. (1998), Caracterização das lagoas Imboassica, Cabiúnas, Comprida e Carapebus a partir da temperatura, salinidade, condutividade, alcalinidade oxigênio dissolvido, $\mathrm{pH}$, transparência e material em suspensão. In - Ecologia das lagoas costeiras do Parque Nacional da Restinga de Jurubatiba e de Macaé (RJ), ed. F. A. Esteves. UFRJ, Rio de Janeiro, pp. 109-122.

Talling, J. F. (1957), Diurnal changes of stratification and photosynthesis in some tropical African waters. Proc. Royal Soc. Lon., 147, 57-83.

Tranvik, L. J. (1989), Bacterioplankton growth, grazing mortality and quantitative relationship to primary production in a humic and clearwater lake. J. Plank. Res., 11(5), 985-1000. 